\title{
RCSD1 Gene
}

National Cancer Institute

\section{Source}

National Cancer Institute. RCSD1 Gene. NCI Thesaurus. Code C119661.

This gene is involved in binding to F-actin. 